\title{
Resource assessment of Silurian and Ordovician shales in the Baltic Basin based on the results of 3D geological modelling - methodological aspects
}

\begin{abstract}
The paper discusses issues of the estimation of hydrocarbon resources accumulated in shale formations. A general overview of the calculation methods used for these types of reservoirs has been presented, based on which two variants of the volumetric method for the calculation of petroleum and/or natural gas resources have been discussed. The second part of the paper presents an example of the use of the described methods for the region of prospecting for unconventional reservoirs in Silurian and Ordovician formations in the onshore part of the Baltic Basin. The calculation procedures were conducted on the basis of a 3D geological model reproducing the geometry and variability of the petrophysical and geochemical properties of shale intervals. The methods of visualisation of the resource calculation results presented as spatial models have also been shown, along with the possibilities of their use for the purpose of the demarcation of optimal zones for placing exploratory and appraisal wells.
\end{abstract}

Key words: resources of shale reservoirs, methods of resources calculation, 3D geological modelling.

\section{Analiza zasobowa łupków sylurskich i ordowickich basenu bałtyckiego na podstawie wyników modelowania geologicznego 3D - aspekty metodyczne}

\begin{abstract}
Artykuł przedstawia problematykę szacowania zasobów węglowodorów zakumulowanych w formacjach łupkowych. Przedstawiono ogólną charakterystykę metod obliczeniowych stosowanych dla tego typu złóż oraz na tym tle dokładniej omówiono dwa warianty objętościowej metody obliczania zasobów geologicznych ropy naftowej i/lub gazu ziemnego. W dalszej części pracy przedstawiono przykład zastosowania opisanych metod dla rejonu poszukiwania złóż niekonwencjonalnych w formacjach syluru i ordowiku w lądowym fragmencie basenu bałtyckiego. Procedury obliczeniowe realizowano na bazie modelu geologicznego 3D odtwarzającego geometrię i zmienność parametrów petrofizycznych i geochemicznych interwałów łupkowych. Przedstawiono również sposoby wizualizacji wyników obliczeń zasobów realizowanych w formie modeli przestrzennych oraz możliwości ich wykorzystania dla celów wyznaczania optymalnych stref dla lokalizowania otworów poszukiwawczych i rozpoznawczych.
\end{abstract}

Słowa kluczowe: zasoby złóż w łupkach, metody obliczania zasobów, modelowanie geologiczne 3D.

\section{Introduction}

The amount of hydrocarbon resources accumulated in shale formations is the most significant factor determining the possible success of development and profitable production of these reservoirs. The calculations presented to date are characterised by considerable dispersion of the obtained results, even by several orders of magnitude $[3,8,10,12]$. On the other hand, these results were obtained using completely different methodological approaches, in some cases making assumptions based on the experience resulting from prospecting for shale reservoirs in the USA.

In the research work performed in the Department of Geology and Geochemistry of the Oil and Gas Institute - National Research Institute as part of the Blue Gas scientific projects, the addressed issues had to do with the adjustment and application of volumetric methods of the estimation of geological resources for shale formations saturated with both natural 
gas (shale gas) and petroleum (shale oil). The work concerned both the methodological aspects of resource calculations as well as their attempted use for a real set of wellbore and seismic data from the area of one of the concessions in the Baltic Basin, where Silurian and Ordovician shale formations are objects of exploration. As part of the methodological work, two separate variants have been developed for the use of the volumetric method for the calculation of resources of hydrocarbons saturating shale formations, based on different sets of input data. At the same time,

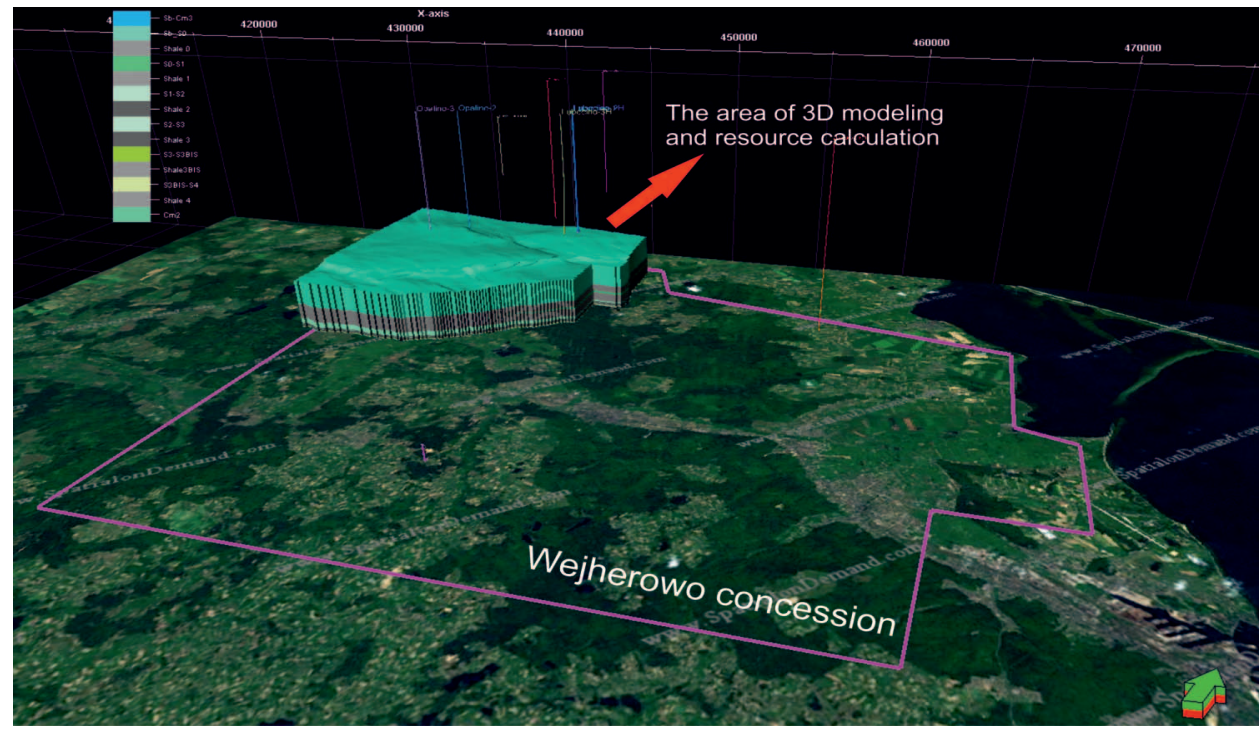

Fig. 1. Location - the area analysed as part of the work involving geological modelling and resource calculations conducted based on 3D models actions were undertaken involving

the integration and interpretation of borehole and seismic data, intended to predict the spatial distributions of the parameters participating in the resource calculation processes. The final stage of work was the performance of resource calculations for the most prospective intervals of Silurian and Ordovician shales within a selected part of the Baltic Basin, based on the results of $3 \mathrm{D}$ modelling. As a result, the spatial distribution of hydrocarbons accumulated within the specific intervals has been determined, indicating the existence of considerable diversity in the amount of resources across the analysed area.

\section{Methodological aspects of the use the volumetric method for the calculation of hydrocarbon resources present in shale formations}

The analysis of the information available in the literature on the methodology used for the estimation of the geological resources of hydrocarbons accumulated in shale formations (gas shales/oil shales) indicates the existence of several methodological approaches, by means of which the resources of unconventional hydrocarbons accumulated in shale formations are estimated. These approaches have been developed for the needs of the resource analyses at various stages of the exploration, development and production of unconventional natural gas and oil reservoirs. Due to this, these approaches are characterised by high diversity with respect to the types of the used geological, geochemical, petrophysical and engineering data. In general, the methods of the estimation of the geological resources of hydrocarbons in shale formations can be divided into several groups [2, 3, 6, 8, 9]:

- the volumetric methods, applied as operations on reservoir maps or models (reservoir model based),

- the material balance methods - geological-geochemical approach, based on an analysis of hydrocarbons generation and dispersion processes in source formations (basin/ petroleum system model based),
- the methods based on an analysis of similarity to analogical but better explored reservoirs. This approach is ussualy used for areas with production data.

At the current stage of exploration for unconventional reservoirs in Silurian and Ordovician shale formations in northern Poland, the most adequate methods for the calculation of geological resources in shale formations seem to be the volumetric methods. In the present paper, the application of methods for the calculation took place by operating on previously constructed structural and parametric models of effective porosity, rock density, TOC, saturation of pore space with water, as well as the $\mathrm{S} 1$ parameter. Considering the results of PVT analyses, as well as the results of the determination of organic matter maturity, it has been concluded that within the analysed area the pore space is saturated with petroleum containing dissolved gas (unsaturated oil). The calculations were performed assuming constant parameters of the reservoir fluid collected from the L-1 borehole.

Two variants of geological resource calculation were analysed and developed, adequate for the zones of saturation of shale formations with petroleum and natural gas. 


\section{Extension of the standard volumetric method by the procedure calculating the amount of adsorbed gas (method I)}

This type of solution was presented, e.g. by [2] and developed in the form of a computational module, compatible with the Petrel software. One of the specific functions of this suite is the ability to determine the varying proportion of saturation of the shale rock with water, oil, condensate and gas in the transitional zones. However, the analysed area lacks a sufficiently identified character and variability of saturation which would enable the use of such detailed calculations (the available data originate from the PVT analyses of one sample of the reservoir fluid from a borehole from the studied area). Assuming one type of saturation of the pore space (i.e. petroleum containing dissolved gas and reservoir water in varying proportion), it is possible to conduct the calculation procedure by means of the standard modules of the Petrel software. The calculation procedure is partially analogical to the one used for conventional reservoirs; the resources of oil in an oil reservoir (STOIIP) and of gas in a gas reservoir (GIIP) are calculated according to the relation describing the volume of the effective pore space within the given volume of the reservoir formation, diminished by the presence of the reservoir water accompanying the hydrocarbons. Knowing the values of the volumetric coefficients for oil and gas $B_{o}$, $B_{g}$, determined based on the PVT laboratory measurement, the resource values are expressed in relation to the standard (surface) conditions. These formulas can be used for the zones of saturation with oil containing dissolved gas, the zones with the presence of condensate, as well as for formations saturated with dry gas $[2,3]$ :

$$
\begin{gathered}
\operatorname{STOIIP}_{-}=\sum_{i=1}^{n b \text { cells }} \frac{V_{i} \cdot \phi_{\text {effi }} \cdot(1-S w)_{i}}{B_{o}} \\
\operatorname{GIIP}_{-\mathrm{I}}=\sum_{i=1}^{n b \text { cells }} \frac{V_{i} \cdot \phi_{\text {effi }} \cdot(1-S w)_{i}}{B_{g}} \\
\operatorname{GIIP}_{\text {w ropieI }}=\operatorname{STOIIP}_{-} \cdot R s=\sum_{i=1}^{n b \text { cells }} \frac{V_{i} \cdot \phi_{\text {effi }} \cdot(1-S w)_{i}}{B_{o}} \cdot R_{S}
\end{gathered}
$$

where:

STOIIP $_{I}-$ oil resources $\left[\mathrm{m}^{3}\right]$,

GIIP $_{I}-$ free natural gas resources $\left[\mathrm{m}^{3}\right]$,

GIIP $_{\text {in_oil_I }}-$ resources of gas dissolved in oil $\left[\mathrm{m}^{3}\right]$ calculated using method I,

$V_{i}$ - cell volume $\left[\mathrm{m}^{3}\right]$,

$\phi_{\text {effi }}-$ effective porosity of the cell $i$,

$S w_{i}$ - saturation of cell with water $i$,

$B_{o}$ - oil volume coefficient (1.5),

$B_{g}-$ gas volume coefficient $(0.005)$,

$R_{s}-$ gas-oil ratio (167.9).
In the abovementioned manner it is possible to calculate the resources of oil or gas saturating the pore space of shale rocks. However, in this type of formation, apart from the free hydrocarbons (in the pore space) there is also gas adsorbed by the kerogen present in the rock. The amount of adsorbed gas depends, among other things, on the organic matter content of the rock, the type of kerogen and the thermal maturity; according to Jarvie, in the American shale reservoirs the adsorbed gas may amount to $10 \div 70 \%$ of the total gas [4].

The aforementioned extension of the standard volumetric method involves also taking into account the hydrocarbons adsorbed on the surface of kerogen. The volume of the adsorbed gas is calculated using the Langmuir isotherm, determined in a laboratory and defining the sorptive capabilities of the rock under specific pressure conditions. An example of the Langmuir isotherm for the samples collected from the Silurian member of bituminous shales from Jantar and from the Ordovician level of the Sasino claystone formation from one of the boreholes from the studied area is presented in Figure 2.

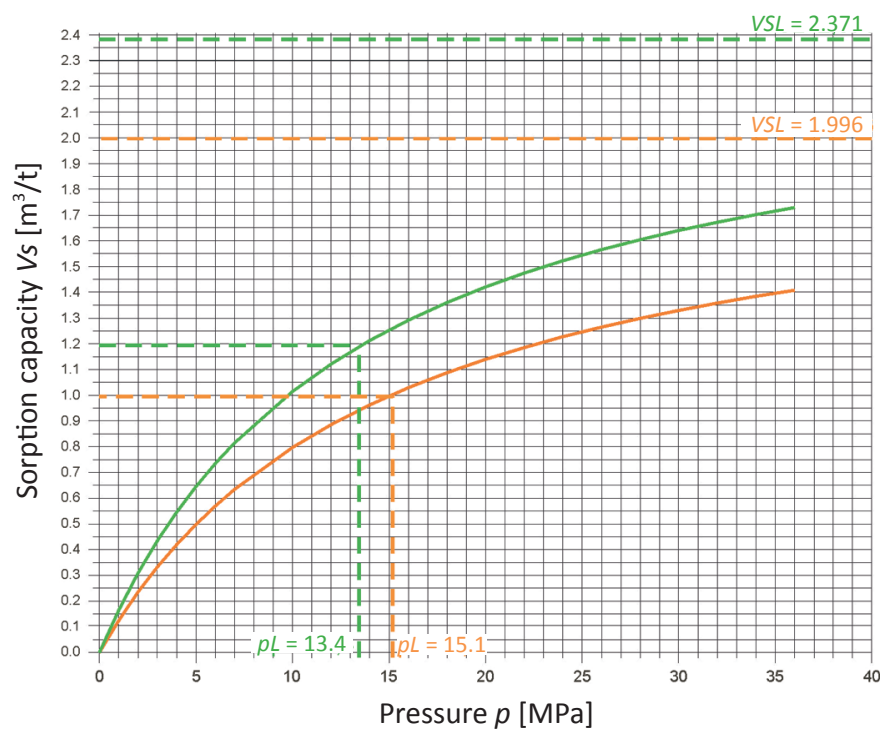

Fig. 2. The Langmuir isotherm for samples collected from the Silurian member of bituminous shales from Jantar (green curve) and from the Ordovician level of the Sasino claystone

formation (orange curve). The VSL parameter indicates the maximum volume of gas which can be adsorbed; $p L$ is the value of pressure at which half of the gas adsorbed at maximum pressure undergoes desorption

The volume of gas adsorbed within a reservoir is calculated by means of the following formulas:

$$
\mathrm{GIIP}_{\text {ads }}=A \cdot h \cdot \rho_{\text {rock }} \cdot V S
$$

GIIP $_{\text {ads }}-$ adsorbed gas resources $\left[\mathrm{m}^{3}\right]$, 
$A$ - deposit area [m],

$h$ - deposit thickness [m],

$\rho_{\text {rock }}-$ rock density $\left[\mathrm{t} / \mathrm{m}^{3}\right]$,

$V s-$ sorption capacity $\left[\mathrm{m}^{3} / \mathrm{t}\right]$.

The Langmuir isotherm enables determining the sorption capacity which corresponds to specified pressure conditions within the analysed interval of the reservoir.

$$
V s=\frac{V L \cdot p}{p L+p}
$$

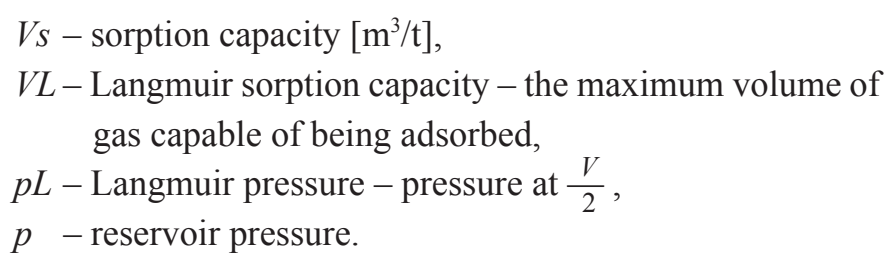

Therefore, the total hydrocarbon resources accumulated in the shale rock interval PIIP (petroleum initially in place) are the sum of free hydrocarbons filling the pore space (in the analysed example it is petroleum with dissolved gas) and the gas adsorbed on the surface of kerogen.

\section{The method based on the geochemical data (Rock Eval), the PVT data, and the Langmuir isotherm (method II)}

The second of the analysed methods for the calculation of hydrocarbon resources accumulated within shale formations is an original proposal of the Oil and Gas Institute - National Research Institute participating in the Blue Gas 1D project. This method uses the geochemical data (Rock Eval), the results of PVT analyses of formation fluids, as well as the Langmuir isotherm, determined in a laboratory and used to estimate the amount of adsorbed gas. This is an extension of the methodology suggested, inter alia, by the British Geological Survey, using the S1 parameter for the calculation of oil resources [13].

This method may be found useful only in an analysis of shaley reservoirs saturated with petroleum (oil shales); it does not require knowledge of the thermodynamic parameters, or having at one's disposal the variation models for effective porosity and saturation with reservoir water. The estimation of the oil volume is accomplished based on the value of the S1 parameter, reflecting the amount of free liquid hydrocarbons present in the rock, which are released in a pyrolytic oven at temperatures of up to $300^{\circ} \mathrm{C}$, and the " $r$ " coefficient reflecting the relation between the $\mathrm{S} 1$ parameter and the amount of liquid hydrocarbons saturating the rock. The total amount of hydrocarbons contained within a rock is calculated based on the results of Rock Eval pyrolytic analyses in relation to the solvent extraction of bitumen from those samples, a double pyrolytic analysis being required for the same sample (before and after the extraction of bitumen). The method used for the determination of the " $r$ " coefficient for a given specified formation is presented in paper [5]. Since the measurements are performed on ground rock samples lacking the lightest hydrocarbon components (C1-C5), which constitute the gaseous phase in a reservoir (gas dissolved in oil or as the free gaseous phase), and the $\mathrm{S} 1$ parameter indicates the mass of petroleum in a rock mass unit $[\mathrm{mg} \mathrm{HC} / \mathrm{g}$ of rock or $\mathrm{kg} \mathrm{HC/tonne} \mathrm{of} \mathrm{rock],} \mathrm{it} \mathrm{is} \mathrm{impossible} \mathrm{to} \mathrm{use} \mathrm{this} \mathrm{method} \mathrm{for}$ formations saturated with free gas.

The suggested calculation of oil resources for a shale rock interval with specified geometry uses the following formula:

$$
\mathrm{STOIIP}_{-} \mathrm{II}=\sum_{i=1}^{n b c e l l s} \frac{V_{i} \cdot \rho_{\text {skaty }_{i}} \cdot S 1_{i} \cdot r}{\rho_{\text {ropy }}}
$$

STOIIP_II - oil resources $\left[\mathrm{m}^{3}\right]$ calculated using method II, $V_{i}$ - the volume of cell $i\left[\mathrm{~m}^{3}\right]$,

$S 1_{i}$ - the oil content of rock [ $\mathrm{t} \mathrm{HC/t}$ of rock] in the given cell $i$ $r$ - the factor of proportionality,

$\rho_{\text {rock }}-$ rock density $\left[\mathrm{g} / \mathrm{cm}^{3}\right]$,

$\rho_{\text {oil }}-$ oil density $\left[\mathrm{g} / \mathrm{cm}^{3}\right]$.

Knowing the value of gas solubility $\left(R_{s}\right)$, it is possible to calculate the resources of gas dissolved in oil GIIP in oil $a c-$ cording to the same relation as in the first method:

$$
\mathrm{GIIP}_{\mathrm{w}_{-} \text {ropie_II }}=\sum_{i=1}^{\text {nbcells }} \mathrm{STOIIP}_{\text {III }} \cdot R_{s}
$$

$R_{s}$ - solubility of gas in oil,

STOIIP $_{\text {II }}-$ oil resources $\left[\mathrm{m}^{3}\right]$,

$\mathrm{GIIP}_{\mathrm{II}}-$ gas resources $\left[\mathrm{m}^{3}\right]$.

Likewise, in relation to the adsorbed gas, the same calculation formulas as shown above are used, being an element extending the standard volumetric method of hydrocarbon resource estimation. Analogically, the total geological resources of the hydrocarbons saturating the shale rock are a sum of the resources of oil saturating the pore space and the gas dissolved in the oil, as well as the adsorbed gas. A more complex description of the methodological assumptions related to the use of the aforementioned calculation procedures has been presented in paper [5]. 


\section{The 3D model of a shale formation}

The calculations of resources according to the abovementioned methods have been tested on a real area of exploration and the 3D models developed for it, also defining, apart from the geometry (volume) of the prospective shale intervals, a set of spatial distributions involving the values of the parameters used in the calculation procedures. The construction of spatial models parametrising the studied geological structure was preceded by a detailed integration and interpretation of the borehole data, the goal of which was to obtain consistent, continuous borehole profiles with parameters determining the resource potential of the shale intervals.

\section{Analyses of geophysical logging data in terms of the consideration of the resources within a shale formation}

An immanent characteristic of all the interpretation procedures developed for the geophysical logging data is the necessity of calibration of the quantitative models constituting their result, using the available geological knowledge and the results of laboratory research. This is the case because none of the interpreted petrophysical parameters being an object of interest for specialists who estimate the potential hydrocarbon resources are measured directly. This fact causes the process of interpretation of the geophysical logging data to constitute a specifically defined field of integration of various data which could be in an overall manner described as "the available geological information". The qualitative information collected during the current stage of exploration of Polish shale formations, along with the available results of laboratory research, unambiguously indicate a very complex image of the structural composition and considerable nonuniformity, both lateral and horizontal, of these parts of Ordovician and Silurian sediment profiles which seem to be the most pro- spective fragments in terms of resources. It is due to their complexity that a quantitative description of the studied formations requires numerous examinations from various fields of geological, geochemical, petrophysical and petrological knowledge, rock mass mechanics, etc. Such a large amount of data cannot be unequivocally used for all the aspects of their variability, and a selection thereof is conducted in a natural manner as part of the constructed mathematical models, in terms of their significance for the examined detailed subjects. So, for the subject of the estimation of potential hydrocarbon resources within the unconventional shale oil or shale gas type reservoirs, methodological assumptions have been developed in the Department of Geology and Geochemistry of the Oil and Gas Institute - National Research Institute for the interpretation of the geophysical logging data and integration of its results in the available space of the results of laboratory examinations, described below and shown in the picture (Fig. 3).

\section{A volumetric model of mineral composition and porosity}

The first and major question that needs to be answered when attempting to estimate the resources is the question about the structure of the reservoir rock, which in the case of unconventional deposits, in which the migration of hydrocarbons after the expulsion phase is minor, is also the question about the structure of the source rock. Using the results of the XRD and NMR examinations, mercury porosimetry, borehole measurements of the GEM neutron-gamma spectrometry, the results of the Rock Eval geochemical examinations, and the techniques for estimation of the TOC content (Total Organic Carbon) $[2,10]$, the volumetric clay grain content is determined first of all, along with the simplified volumetric model of the mineral composition, grouping the minerals with similar physical properties: quartz, feldspars, plagioclases into the $\mathrm{Q}+$ Sk component; calcite, dolomite, ankerite into the carbonate group; the amount of organic matter in the form of kerogen and the total porosity. Obviously, the number and type of the discerned mineral groups depend on the minuteness of the laboratory examinations and the specific amounts of the individual minerals. In many cases, a group of minerals containing iron is also distinguished: pyrite, marcasite, siderite, even a small amount of which greatly affects the petrophysical parameters of the analysed formations. Such an approach is undoubtedly advantageous from the mathematical standpoint, since lowering the number of unknowns always benefits the statistics of the solution and its stability.

\section{The analysis of porosity}

Porosity is the characteristic of a shale formation which, next to the organic matter content, directly decides about the possibility of hydrocarbon accumulation. In this case, however, the knowledge about its distribution in the rock is of the utmost significance. Which is why, apart from the standard term, in the case of unconventional reservoirs, effective porosity, interpreted 
as the result of subtracting the volume of water bound with clay from the total porosity, the term open porosity has been introduced, calculated independently based on the porosimetric measurements, determining, among other things, the percentage of pores with diameters exceeding $10 \mathrm{~nm}$, which size is commonly accepted as the Darcy flow threshold. In order to obtain a continuous open porosity curve, the ratio of open porosities determined in a laboratory to total porosities (several dozen samples in the Silurian and Ordovician intervals) has been correlated with the amount of non-clay minerals determined based on the geophysical logging curves and calibrated with the laboratory data. As is clearly visible (Fig. 3 - the "POROSITY ANALYSIS" column), the open porosity described in such a manner equals the effective porosity in intervals in which no significant presence of organic matter - kerogen - is observed. The presented approach towards the porosity analysis additionally allowed for the estimation of organic matter porosity [7]. However, at the current stage there are no significant laboratory data which could be used for the calibration of this parameter; therefore, this subject requires further study.

\section{The analysis of saturation}

The final parameter, which has a crucial meaning when discussing the resources, is the assessed saturation of shale rock with hydrocarbons. The data for the calibration are provided by the measurements of desorption, ultimately determining the total gas content as the sum of the lost gas, desorbed gas and residual gas, as well as by the Dean-Stark and Rock Eval measurements estimating the liquid hydrocarbon and water content. The correlation of a representative number of

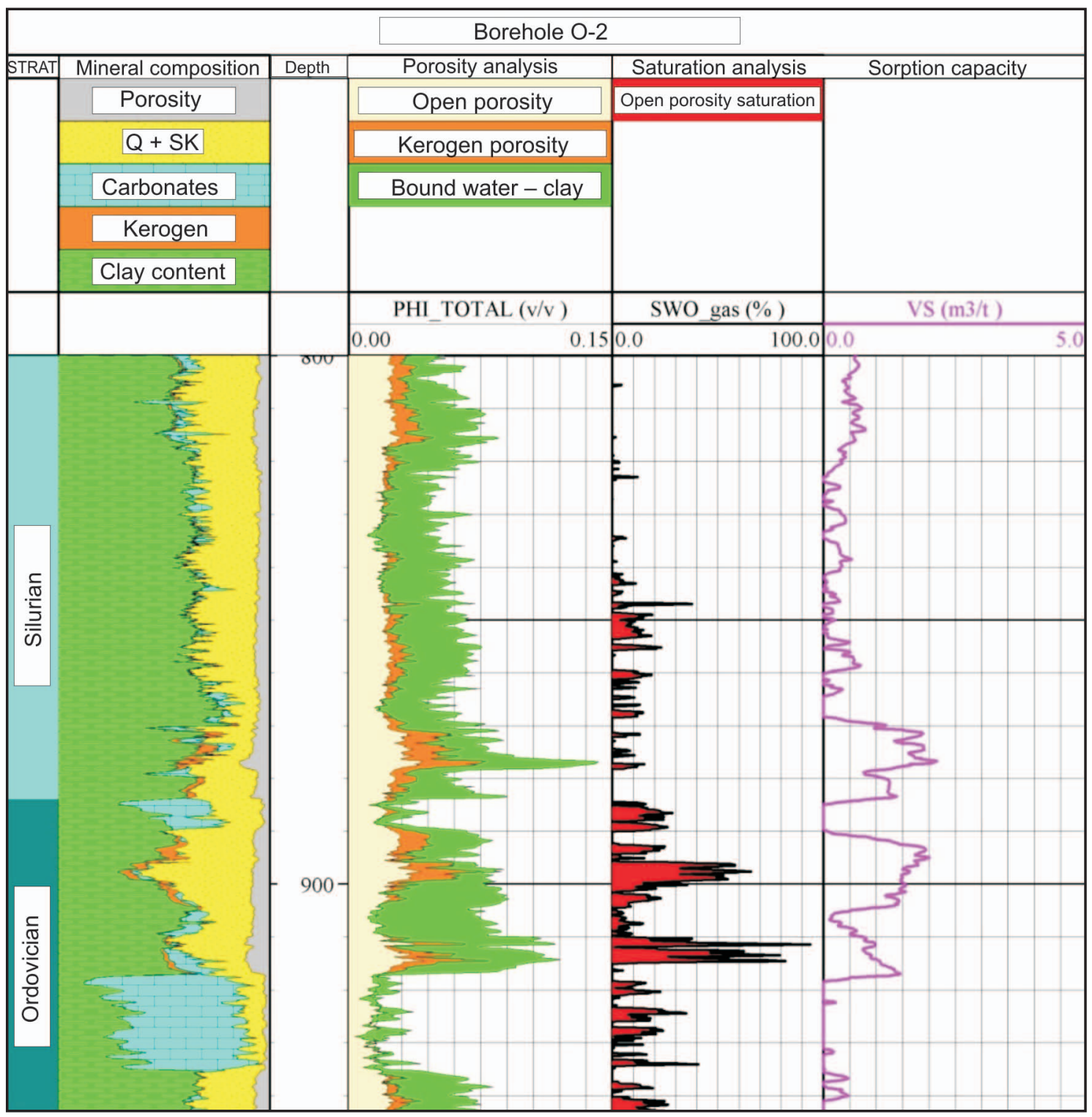

Fig. 3. Sample results of the analysis of geophysical borehole logging data in shale formations as input data for the discussion of resources in the O-2 borehole 
laboratory data determining the saturation with bitumen with the geophysical logging curves made it possible to calculate the free hydrocarbon content. Having adjusted this data for deposit conditions, it was possible to evaluate saturation with free hydrocarbons in open porosity and provide a continuous estimation of the gas sorption capacity $V_{s}\left[\mathrm{~m}^{3} / \mathrm{t}\right]$, which, according to the authors, sufficiently defines the resource prospectiveness of the analysed sediments.

\section{D models of petrophysical and geochemical parameters of shale formations}

The spatial form of calculations and analyses of hydrocarbon resources saturating the shale formations requires the development of spatial distribution models for the parameters determining their resource potential. In order to calculate the resources of hydrocarbons accumulated in intervals comprising the Jantar member and the Sasino formation sediments, $3 \mathrm{D}$ distributions have been modelled for the following petrophysical and geochemical properties of rocks: bulk density, total and effective porosity, organic matter content (TOC), saturation of the pore space of shale rocks with reservoir water $(S w)$, as well as the $\mathrm{S} 1$ parameter reflecting the amount of free hydrocarbons in the rock sample undergoing pyrolysis (Fig. 4). The following were used as input data: results of laboratory measurements, effects of the interpretation of geophysical borehole logging data, as well as the seismic data in the form of the results of simultaneous inversion and the attributes of the seismic trace. A detailed discussion of the methods used for the construction of geological shale formation models has been presented in the authors' separate paper "3D geological modelling for the prospectiveness evaluation of shale formations".

The results of geological modelling, executed in a spatial form, enabled a quantitative evaluation of the prospectiveness of shale rocks and a spatial form of the prognosis regarding the distribution of hydrocarbon resources accumulated in unconventional shale formations.

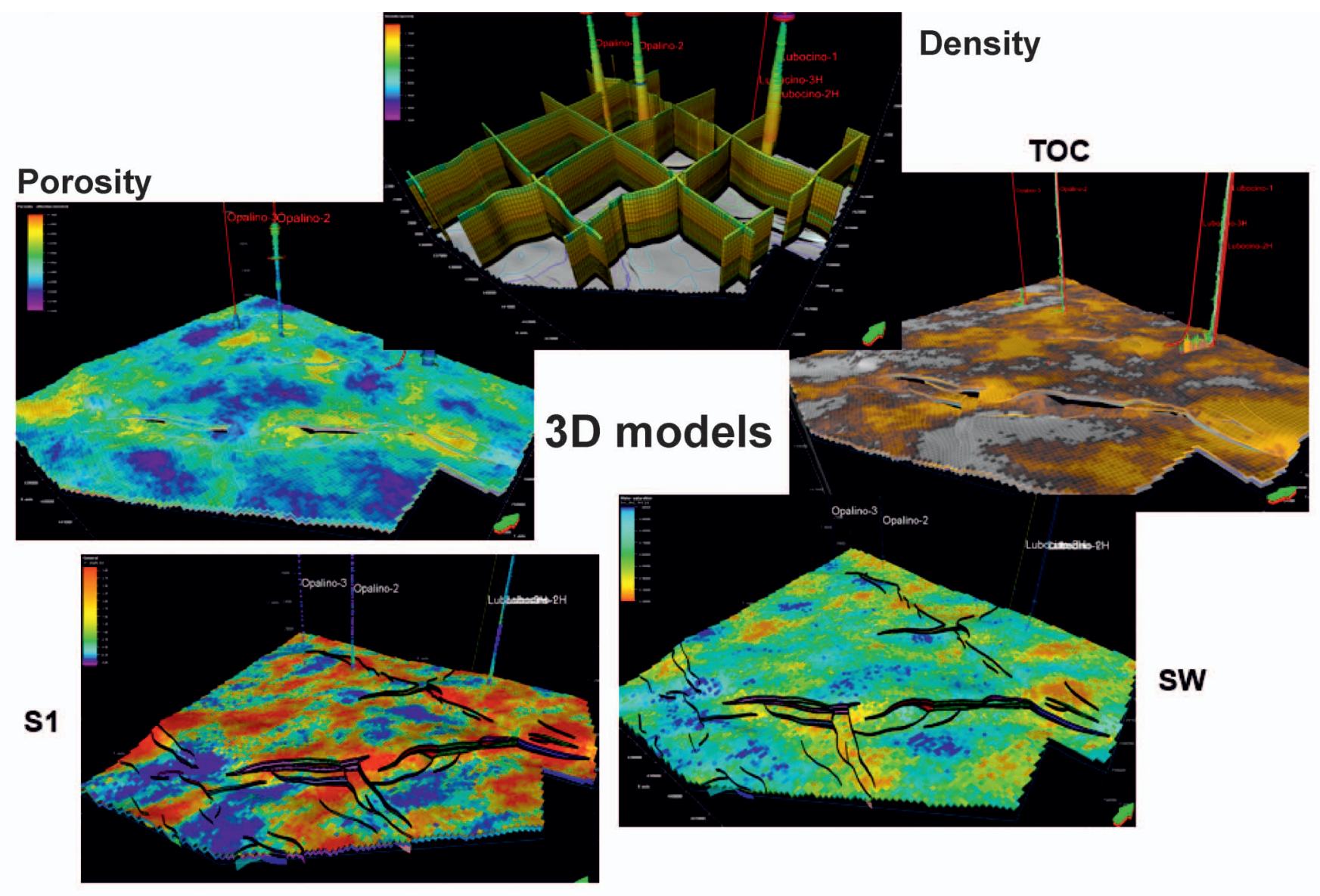

Fig. 4. A set of models of petrophysical and geochemical parameters of the analysed shale formations, used for the calculations of the spatial distribution of hydrocarbon resources 


\section{Resource analysis based on 3D models}

The resource calculations (according to the abovementioned formulas (1-6)) involved the use of 3D models so that full sets of calculation procedures were conducted for each block (cell) of the 3D model. The spatial distribution of hydrocarbons within the analysed intervals of the Jantar member and the Sasino formation was obtained in this manner. The Net to Gross parameter, reflecting the ratio of effective to total volume of the 3D model blocks, was not used in these calculations, having assumed that a proper definition of this parameter requires a better understanding of the permeability of the analysed shale rocks, along with the confirmation of the productivity of the selected fragments of shale intervals based on hydrodynamic tests. However, an attempt was made to replace that parameter by increasing the minuteness of the interpretation of the effective porosity, involving the calculation of well logs and a 3D model of this part of effective porosity, which consists of pores with diameters exceeding $10 \mathrm{~nm}$, therefore enabling the flow of gas according to Darcy's law.

The calculated results are presented below in the form of $3 \mathrm{D}$ visualisations (Figs. 5 and 6). The colour chart corresponds to the hydrocarbon content (oil or gas), recalculated for surface conditions in a single block of the spatial model, whose average volume is $100 \times 100 \times 1.6=16000 \mathrm{~m}^{3}$. In the case of the average value maps, they reflect the magnitude of oil or gas resources within the full thickness of the given interval over a unit of area (1 ha).

The comparison of the results obtained using both methods indicates the existence of considerable lateral and vertical diversity of the resources within the analysed shale intervals. In effect, the sum of hydrocarbons saturating the shale level in the individual zones of the studied area may be even several times higher or lower, which undoubtedly affects the possibility of the commercial development of the boreholes drilled in various locations.

In both cases of the used methods, the occurrence of similar variation trends is observed regarding the oil and gas reservoirs. A slightly higher range of values obtained using method I (Fig. 5) results from the fact of utilising the effective porosity parameter, taking into account the entire pore space within the analysed shale formations. Limiting the effective porosity parameter by the pore space consisting of pores with diameters below $10 \mathrm{~nm}$, a very high degree of similitude has been obtained for the results of both presented calculation methods (a difference of $5 \div 10 \%$ ). It should be emphasised that the results obtained using both methods in question are
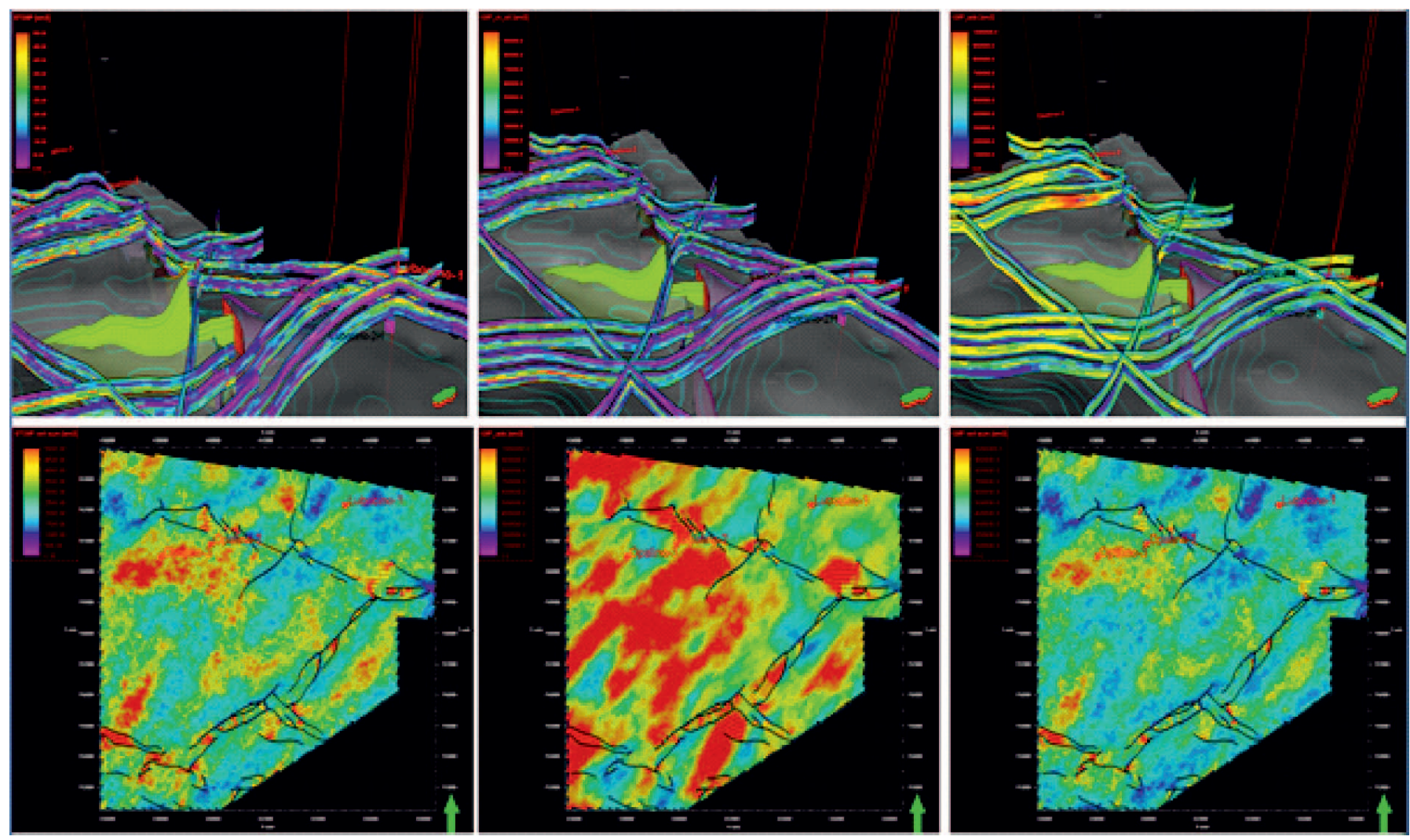

Fig. 5. Visualisation of the results of spatial resource analysis, utilising the first presented calculation method for the Jantar member and the Sasino formation sediments; upper row - distribution of resources as 3D models - respectively showing the resources of:

oil, gas dissolved in oil and adsorbed gas, below - maps of average values of these parameters for the Sasino formation 

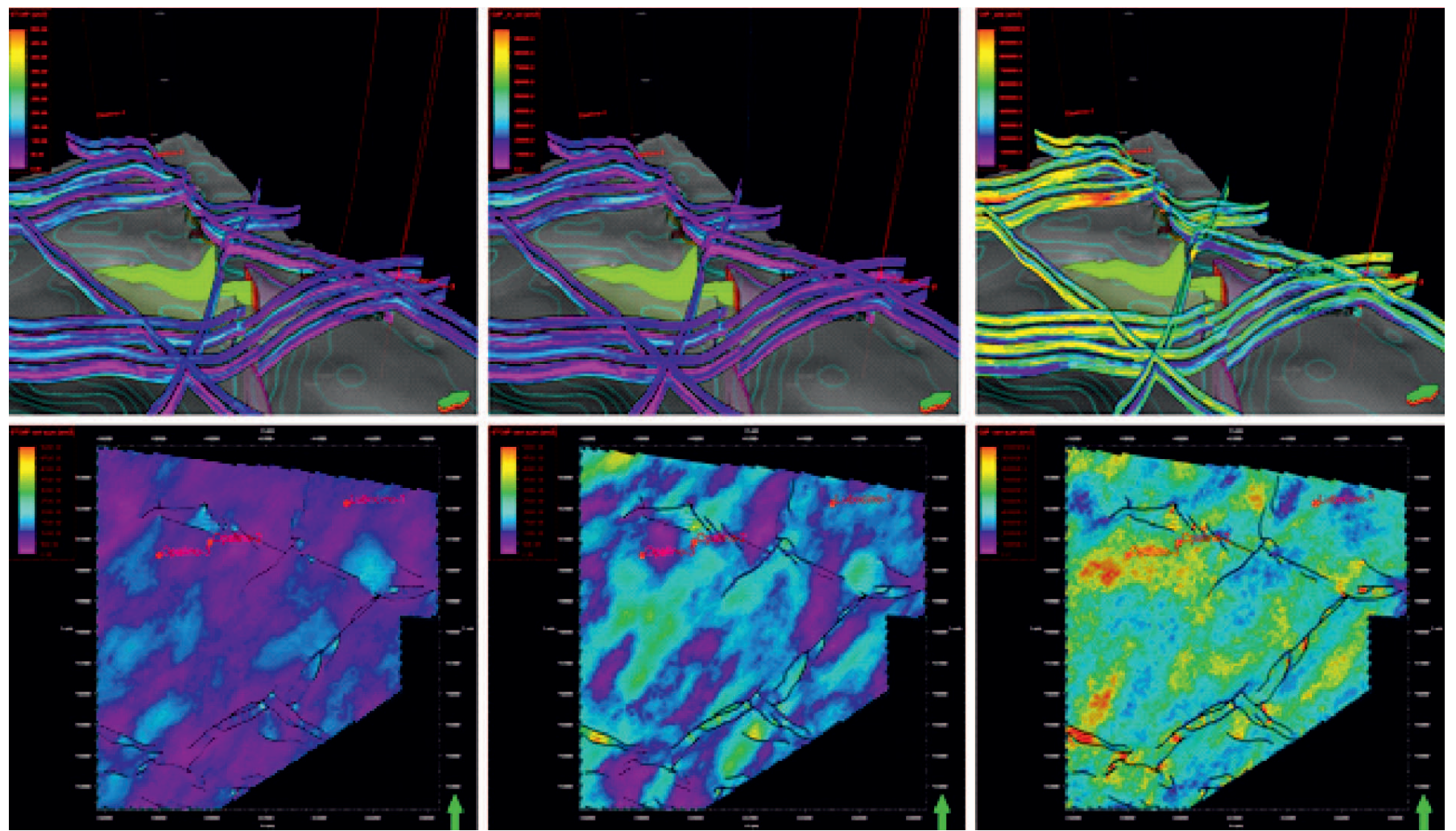

Fig. 6. Visualisation of the results of spatial resource analysis, utilising the second presented calculation method for the Jantar

member and the Sasino formation sediments; upper row - distribution of resources as 3D models - respectively showing the resources of: oil, gas dissolved in oil and adsorbed gas, below - maps of average values of these parameters for the Sasino formation

subject to a considerable extent of uncertainty, resulting from the low degree of recognition (a complete set of data from three boreholes) of the variability of the parameters determining the resource potential of the analysed shale formations.

\section{Conclusions}

1. Methodological assumptions have been formulated and two methods have been used to calculate the geological resources of hydrocarbons accumulated within intervals of the analysed shale rocks, obtaining relatively similar results. One advantage of the possibility of using different methodological approaches is the fact that they require the availability of a different set of data, therefore making it possible to conduct calculations under different conditions of data availability.

2. The calculation of resources as spatial distributions vastly extends the possibilities of analysing and interpreting the results with respect to the identification of zones with optimal parameters of shale formations for the purposes of well placement and its trajectories design. On the one hand, this kind of approach implies the necessity to obtain and integrate a wide spectrum of geological-geophysical data, while on the other hand it allows for the control of the coherence of the individual data types, increasing the credibility of the results of the resource analyses.

3. The observed high variability (lateral and in a vertical profile) of the values of the resources accumulated in shale formations indicates the possibility of obtaining entirely different results from boreholes drilled in the following zones of the explored areas. Within the analysed area these differences were severalfold (between the zones of the largest and the smallest resources), therefore being capable of having a crucial meaning for the possibilities of the commercial utilisation of boreholes and the individual fragments of an unconventional reservoir.

Please cite as: Nafta-Gaz 2015, no. 12, pp. 953-962, DOI: 10.18668/NG2015.12.03

Article contributed to the Editor 4.09.2015. Approved for publication 10.11.2015.

The article is the result of research conducted in connection with the project: Selection of optimal methods for estimation of resources and (geological and commercial) risk at prospecting stage in relation to unconventional "shale gas", "shale oil" and "tight gas" 
deposits in Poland, and development of methods for documentation of unconventional deposits, co-funded by the National Centre for Research and Development as part of the programme BLUE GAS - POLISH SHALE GAS. Contract No. BG1/ŁUPZAS/13.

\section{Literature}

[1] Bowman T.: Direct method for Determining Organic Shale Potential From Porosity and Resistivity Logs to Identify Possible Resource Plays. AAPG Annual Convention \& Exhibition, New Orleans, April 2010.

[2] Bruyelle J., Guerillot D.: An Accurate Volumetric Calculation Method for Estimating Original Hydrocarbons in Place for Oil and Gas Shales including adsorbed Gas using HighResolution Geological Model. International Petroleum Technology Conference, Doha 19-22 January 2014.

[3] Guidelines for Application of the Petroleum Resources Management System. Chapter 4: Assessment of Petroleum Resources Using Deterministic Procedures, November 2011. SPE, AAPG, WPC, SPEE, SEG.

[4] Jarvie D. M., Hill R. J., Ruble T. E., Pollastro R. M.: Unconventional shale-gas systems: The Mississippian Barnett Shale of north-central Texas as one model for thermogenic shale-gas assessment. AAPG Bulletin 2007, vol. 91, no. 4.

[5] Kaczmarczyk W., Sowizdzal K., Sloczynski T.: Methodological aspects of hydrocarbon shale resources assessment using different variants of volumetric methods. Nafta-Gaz 2015, no. 6 , pp. $41-48$

[6] Klett T. R., Charpentier R. R., Cook T. A.: Overview of Assessment Methodologies Continous Gas Accumulations. AAPG GTW Assessment of Unconventional Gas Resources. Istanbul 24-26 May 2010.

[7] Kuchinskiy V.: Organic Porosity Study: Porosity Development within Organic Matter of the Lower Silurian and Ordovician Source Rocks of the Poland Shale Gas Trend. Online Journal for E\&P Geoscientists 2013

[8] Lyster S.: Quantification of Uncertainty in Shale Gas

Marek STADTMÜLLER M.Sc. Eng.

Chief Engineering and Technical Specialist

Department of Geology and Geochemistry

Oil and Gas Institute - National Research Institute

ul. Lubicz 25 A

31-503 Kraków

E-mail: marek.stadtmuller@inig.pl

Anita LIS-ŚLEDZIONA M.Sc. Eng.

Technical and Engineering Specialist

Department of Geology and Geochemistry

Oil and Gas Institute - National Research Institute

ul. Lubicz 25 A

31-503 Kraków

E-mail: anita.lis@inig.pl
Resource Estimates. Energy Resources Conservation Board, Edmonton 2012

[9] McGlade C., Speirs J., Sorrell S.: Methods of estimating shale gas resources - comparison, evaluation and implications. Energy 2013, vol. 59, pp. 116-125.

[10] Assessment of shale gas and shale oil resources of the Lower Paleozoic Baltic - Podlasie - Lublin basin in Poland. First Report. PIG - PIB, Warsaw, March 2012.

[11] Passey Q. R., Creaney S., Kulla J. B., Moretti F. J., Stroud J. D.: A Practical Model for Organic Richness from Porosity and Resistivity Logs. AAPG Bulletin 1990, vol. 74, pp. 1777-1794.

[12] Technically Recoverable Shale Gas and Shale Oil Resources: An assessment of 137 Shale Formations in 41 Countries Outside the United States. EIA/ARI World Shale Gas and Shale Oil Resource Assessment, June 2013. Advanced Resources International, Inc.

[13] www.gov.uk/government/uploads/system/uploads/attachment_data/file/360473/BGS_DECC_MVS_2014_APPENDICESABDEF.pdf (acces on: October 8, 2015).

Krzysztof SOWIŻDŻAŁ Ph.D. Eng.

Assistant Professor, Department of Geology and Geochemistry

Oil and Gas Institute - National Research Institute

ul. Lubicz 25 A

31-503 Kraków

E-mail: krzysztof.sowizdzal@inig.pl

Weronika KACZMARCZYK M.Sc. Eng.

Engineering Support Specialist, Department of Geology and Geochemistry

Oil and Gas Institute - National Research Institute

ul. Lubicz 25 A

31-503 Kraków

E-mail: weronika.kaczmarczyk@inig.pl

Tomasz SŁOCZYŃSKI M.Sc. Eng.

Senior Research Support Specialist, Department of Geology and Geochemistry

Oil and Gas Institute - National Research Institute

ul. Lubicz 25 A

31-503 Kraków

E-mail: tomasz.sloczynski@inig.pl 